\title{
Balochi Language
}

National Cancer Institute

\section{Source}

National Cancer Institute. Balochi Language. NCI Thesaurus. Code C153849.

An Indo-European language that is the principal language of the Baloch people, spoken primarily in Iran, Pakistan and Afghanistan. 